\title{
FAULT IDENTIFICATION FOR THE CATASTROPHIC 1894 ATALANTI EARTHQUAKE USING 3D FINITE-DIFFERENCE MODELING AND LOCAL GEOPHYSICAL DATA
}

\author{
Evangelos MOUZAKIOTIS ${ }^{1)}$ *, Vassilios KARASTATHIS ${ }^{1)}$, Nikolaos VOULGARIS ${ }^{2)}$, \\ Panagiotis PAPADIMITRIOU ${ }^{2)}$, Sotirios SBORAS ${ }^{1)}$ and Ilias GEROLYMATOS ${ }^{3)}$
}

1) Institute of Geodynamics, National Observatory of Athens, Athens, Greece

2) Department of Geology, National Kapodistrian University of Athens, Greece 3) EYDAP S.A. (Athens Water Supply and Sewerage Company), Greece

*Corresponding author's e-mail: aggelmo@noa.gr

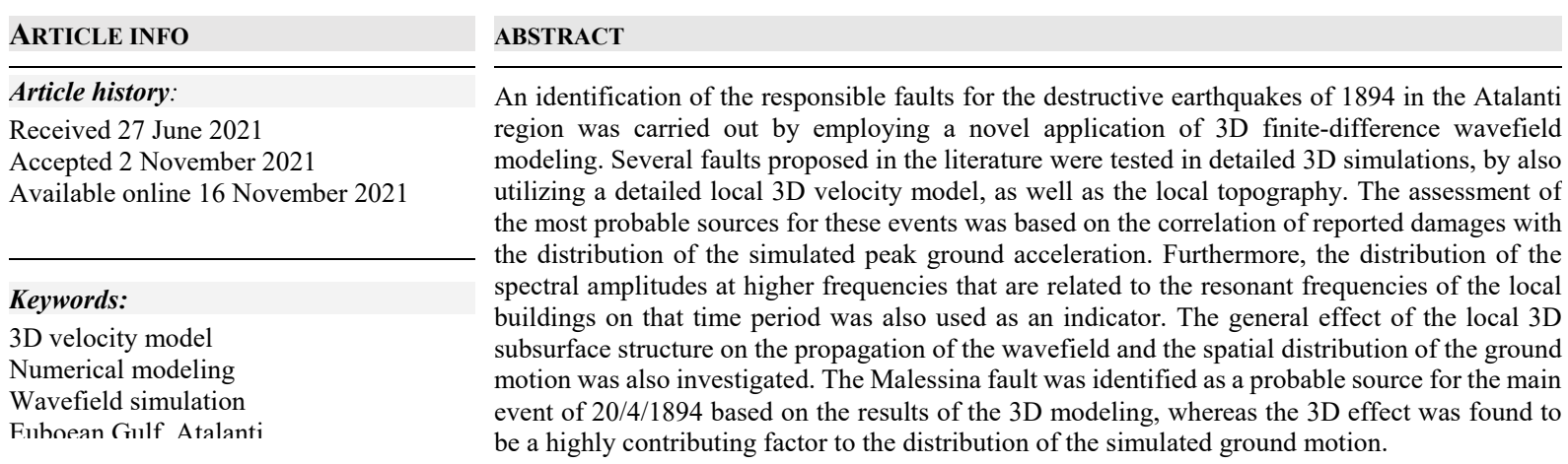

\section{INTRODUCTION}

Active tectonics usually form structures and geomorphological features such as basins and grabens that have a significant effect on a propagating seismic wavefield, causing complex wave phenomena such as multiple reflections or the creation of highly destructive surface waves (e.g. Rayleigh waves). The effect of the earth's three-dimensional structure in the ground motion has been extensively documented in the literature (Bard and Bouchon, 1980; Joyner et al., 1981; Bard and Gariel, 1986; Yilmaz et al., 2006; Karastathis et al., 2010; Novikova et al., 2017) with some prominent examples including the M8.0 earthquake in Mexico in 1985 (Chavez-Garcia and Bard, 1994) and the M6.9 earthquake in Kobe, Japan in 1995 (Pitarka et al., 1998). In such cases, the seismic motion can be amplified by several times due to the effect of the complex sedimentary basin, on top of the amplification caused by the soil layering (e.g. Semblat, 2011). Likewise, the impact of the topography is also of high importance in regions with complex topographical relief, as proven by several studies in the past (e.g. Frankel, 1993; Pitarka et al., 1998; Hestholm et al., 2006).

The calculation of the 3D effect can be made by using 3D modeling techniques in time or frequency domain, such as the Finite difference (e.g. Virieux, 1984; Levander, 1988; Graves, 1996; Zhang et al., 2012; Rubio et al., 2014), the Finite element (e.g. Zienkiewicz, 1977; Padovani et al. 1994; Liu et al., 2014a), the spectral element (e.g. Faccioli et al., 1996; Komatitsch and Vilotte, 1998; Kaneko et al., 2008), the boundary element (e.g. Chen and Zhou, 1992; Álvarez-Rubio et al., 2004) and the discontinuous Galerkin method (e.g. de la Puente et al., 2009; Pelties et al., 2012; Tago et al., 2012). Using the methodologies above, subsurface structure of various levels of $3 \mathrm{D}$ heterogeneity can be incorporated in the simulation of the propagation of the seismic energy. The downside of these methods, however, is the relatively high computational cost that limits their use, since large scale computer systems need to be employed in order to carry out large scale simulations: e.g. the TeraShake simulation (Minster et al., 2004), the Tangshan earthquake simulations by $\mathrm{Fu}$ et al. (2017), etc. Furthermore, each of these methods has an intrinsic disadvantage such as numerical dispersion in the finite element method (Bonilla, 2002) or the limitation to models with weak heterogeneities in the boundary element method (Semblat, 2011). The continuous improvement of home and professional computers, as well as the discovery of various 


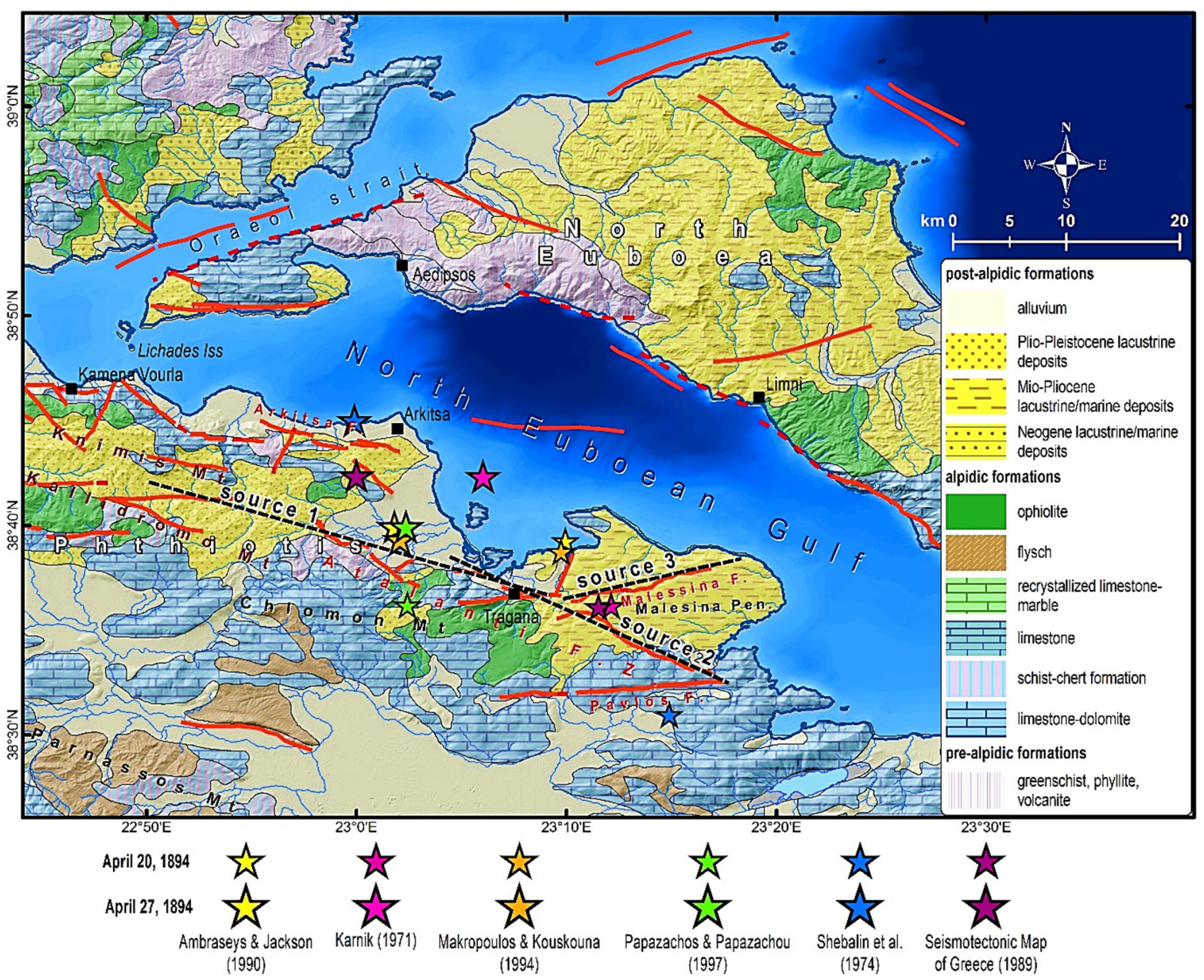

Fig. 1 The region of the North Euboean Gulf. The proposed epicentres for the two strong events of 1984, as proposed by different authors in the literature, the active faults in red lines (see text for references), and the main geological formations (modified after IGME, 1983), are shown on the map. The fault sources that were used for the simulations in the present manuscript are also presented with thick, dashed, black lines.

computational techniques, aimed at reducing the computational requirements for processing very large amounts of data, has greatly contributed to making these techniques more applicable.

In the present study we employ the 3D staggeredgrid finite-difference modeling technique in Greece and more specifically in the North Euboean Gulf (Fig. 1), a tectonic graben formed by a series of parallel NNW-SSE trending normal faults. Greece is one of the most seismically active regions in Europe and is characterized by a complex geology, dominated by a variety of 3D structures, including many grabens. Some well-known cases include the Gulf of Corinth, the Western Gulf of Patras, the North and South Euboea Gulf, etc. (e.g., Ferentinos et al., 1985; Leeder and Jackson, 1993). The region of the North Euboean Gulf is characterized by a relatively high seismicity, having been struck by various strong earthquakes in the past. The oldest catastrophic event occurred in 426 BC (Papazachos and Papazachou, 2003; Ambraseys, 2009; Kanellopoulos et al., 2020) which, according to the historical sources, submerged part of the Lichades volcanic island complex and the narrow isthmus linking the mainland with the Atalanti islet were, making the latter a permanent island, and dried up the hot springs of Aedipsos, where, three days later, new hot springs appeared in new locations. The most recent and most notable events are the two successive strong earthquakes that struck the region in 1894, with estimated magnitudes between M6.4-6.7 for the first (Karnik, 1971; Ambraseys and Jackson, 1990; Papazachos and Papazachou, 2003) and M7.0 (Ambraseys and Jackson, 1990; Makropoulos and Kouskouna, 1994; Novikova et al., 2017) for the second that caused widespread damage in the region. Besides the primary ground deformation phenomena (coseismic ground ruptures), the sequence caused several secondary ones, such as liquefaction, landslides, rockfalls, tsunami and hot-springs anomalies (Papazachos and Papazachou, 2003; Ambraseys and Jackson, 1990; Ambraseys, 2009; Kanellopoulos et al., 2020 and references therein).

The above 3D modeling methodology was used in order to simulate the ground motion caused by the 
historic and catastrophic event of 20/4/1984 in Malessina peninsula, which caused widespread damage in the broader study area (Fig. 1). The actual source of this event has been a subject of investigation by several authors in the past (e.g. Ganas et al., 1998; Pantosti et al., 2001; Albini and Pantosti, 2004). The aim of our work is to provide further insight into the possible fault related to this event by evaluating the catastrophic results of the earthquake, taking advantage of the intrinsic capabilities of 3D numerical modeling to simulate the complex $3 \mathrm{D}$ effect and thus provide a link between the observed localized damages and the maximum simulated amplitudes of the ground motion. We carried out simulations using sources proposed in bibliography and more specifically a) the Atalanti segment of the Atalanti fault zone (Ganas, 1997; Pantosti et al., 2001; Pavlides et al., 2004; Karastathis et al., 2007), b) the faults proposed by Albini and Pantosti (2004), based on macroseismic observations and c) the Malessina fault (Pantosti et al., 2001; Gerolymatos and Stefouli, 2020). The above tested sources are shown in Figure 1. By simulating the ground motion from these sources, our aim is to examine the effect of the $3 \mathrm{D}$ subsurface structure and investigate the correlation of the reported damages with the calculated ground motion in the area. Furthermore, our goal is to assess the most suitable source for the events that can justify the reported intensities and results. For this purpose, we utilized a detailed 3D velocity model for the region available by Karastathis et al. (2011), in combination with the local topography.

\section{GEOLOGICAL-TECTONIC AND GEODYNAMIC SETTING}

The study area lies between two major active tectonic regimes: i) the westward prolongation of the transcurrent North Anatolian Fault, i.e. the North Aegean Trough and Basin (e.g. Lybéris, 1984; Sboras et al., 2017), and ii) the extensional structure of the Gulf of Corinth (e.g. Ori, 1989; Nixon et al., 2016). The N-S-trending crustal stretching (e.g. Hatzfeld et al., 1999) has produced WNW-ESE- to NW-SEstriking extensional faulting which has thinned the crust to $20 \mathrm{~km}$ below northern Evoikos Gulf (Makris et al., 2001), also directly affecting the landscape (Poulimenos and Doutsos, 1997; Goldsworthy and Jackson, 2001). The Gulf represents a ca. $100 \mathrm{~km}-\mathrm{long}$ (half-) graben/rift (Roberts and Jackson, 1991), bordered by large fault zones of discontinuous faults which cause vertical movements (Stiros and Rondogianni, 1985; Poulimenos and Doutsos, 1997; Papanastassiou et al., 2014) as also suggested by shoreline changes along the Euboean and Phthiotis (Stiros et al., 1992; Evelpidou et al., 2011). On the mainland (Phthiotis region), parallel to the southwestern coastline of the gulf, roughly NEdipping normal faults have significantly affected the topographic relief by forming elongated mountain ranges on their footwall (e.g. Mts. Kallidromo and Knimis), and the drainage evolution (e.g. Kranis et al.,
2001; Palyvos et al., 2006). Among these faults, the seismic Atalanti Fault stands out for possibly producing the 1894 M7.0 homonymous earthquake (e.g., Ganas et al., 1998; Pantosti et al., 2001; information about the local geological conditions see Kanellopoulos et al. (2015) and references therein), whereas an impressive $40 \mathrm{~m}$-high, striations and corrugations-bearing fault surface, named 'Arkitsa fault', has been exposed after the excavation of the covering colluvial deposits (e.g. Jackson and McKenzie, 1999; Resor and Meer, 2009). Less investigated, northern Euboea also demonstrates ca. WNW-ESE-striking neotectonic structures revealing NNW-SSE-oriented, Quaternary extension (Mettos et al., 1991). Crosswise to the above faults, in ENE-WSW to NE-SW general direction, active faults have been detected on land, both in Phthiotis region and North Euboea (Kranis et al., 2001; Palyvos et al., 2006). Focal mechanisms also confirm the offshore occurrence of such faulting orientation (Benetatos et al., 2004). The occurrence of the Lichades-Kammena Vourla volcanic centre (Kanellopoulos et al., 2019) and the hot-springs on both coasts of the gulf (Kanellopoulos et al., 2018, 2020) are related to this tectonic setting.

\section{DATA AND METHODOLOGY}

The methodology that was used in order to carry out all simulations is the 3D finite-difference technique, using the staggered grid scheme. With the above method, the three velocity components ( Vx, Vy and $\mathrm{Vz}$ ) and the 6 stress components (txx, tyy, tzz, txy, txz and tyz) are calculated in a successive manner. More specifically, at each time step the spatial and time derivatives of the stress components are used to update the velocity values, followed by the calculation of the spatial and time derivatives of the updated velocity values that are then used in turn to calculate the new stress values. In our case we used the $4^{\text {th }}$ order scheme (with the coefficients provided by Levander (1988)) for the calculation of the spatial derivatives, as it provides more accurate and stable results compared to the $2^{\text {nd }}$ order scheme, while retaining computational efficiency (Levander, 1988; Hustedt et al., 2004) and the $2^{\text {nd }}$ order scheme for the time derivatives.

This procedure was applied for the simulation of propagating wavefields in region of the North Euboean Gulf that covers an area of $54 \times 78 \mathrm{~km}$. The subsurface structure of this region has been studied by Karastathis et al. (2011), who provide a detailed 3D V $V_{P}$ and $\mathrm{V}_{\mathrm{S}}$ velocity model for the region that covers depths up to $20 \mathrm{~km}$. The $\mathrm{V}_{\mathrm{P}}$ velocity model and the $\mathrm{V}_{\mathrm{P}} / \mathrm{V}_{\mathrm{S}}$ ratio that were used as input are presented in Figure 2. Additionally, a topographic and bathymetric model with $100 \mathrm{~m}$ resolution was implemented. In order to generate results at higher frequency bands, it is required to discretize the volume in a dense grid of nodes. Consequently, in order to ensure numerical stability, it is crucial to use a small time step. In our case we applied linear interpolation to the $3 \mathrm{D}$ velocity model of Karastathis et al. (2011), which initially had 

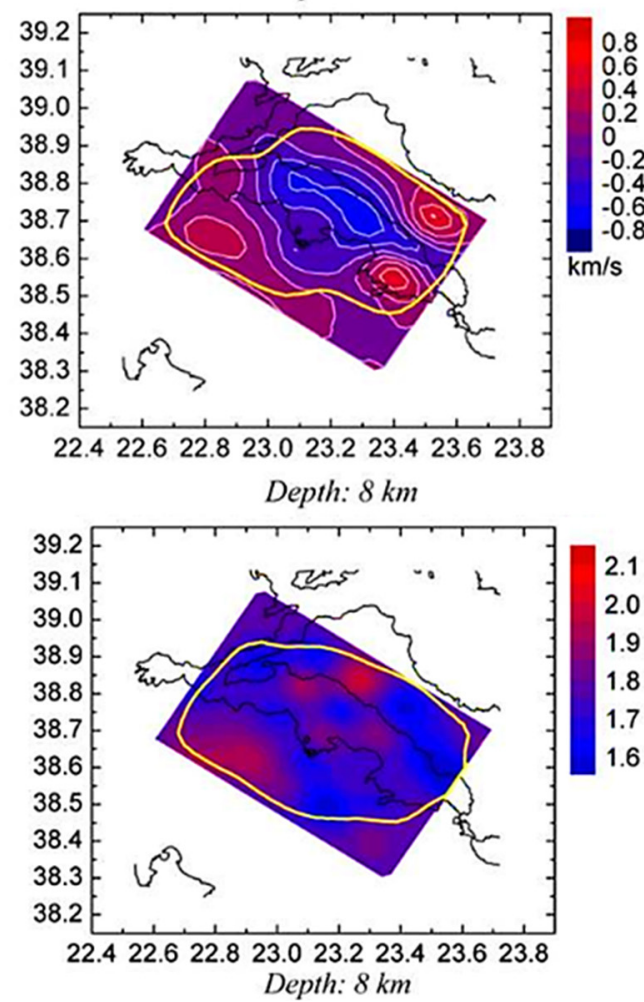
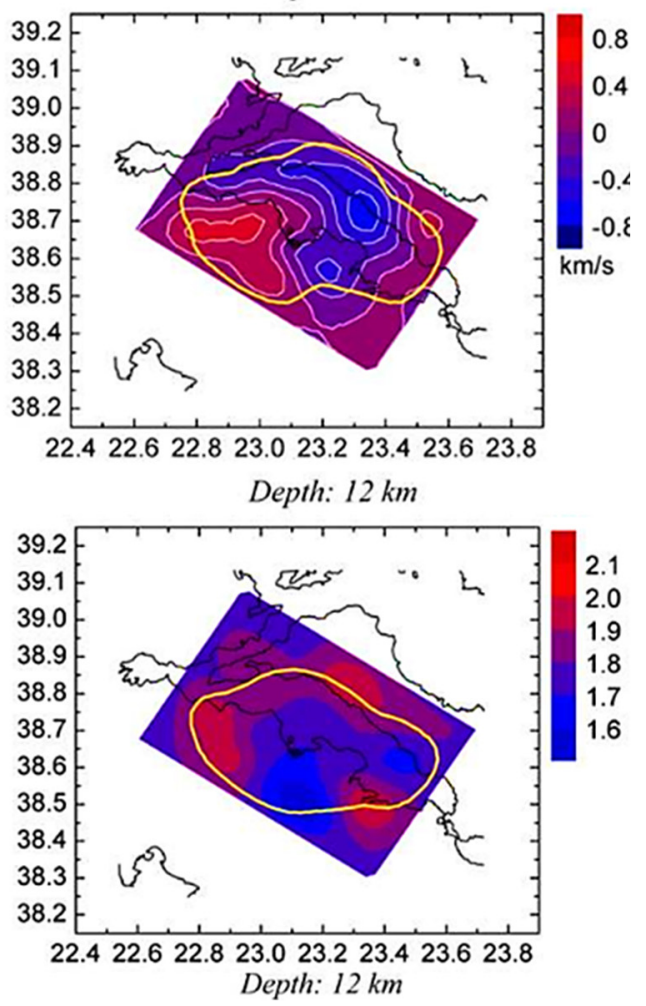

Fig. 2 Depth slices of the $V_{P}$ velocity perturbations (top panels) and the $V_{P} / V_{S}$ ratio that was used as input for the simulations in this study (by Karastathis et al., 2011).

a variable node spacing between 9 to $13 \mathrm{~km}$ in the horizontal and 3 to $4 \mathrm{~km}$ in the vertical plane, resulting in a node spacing of $100 \mathrm{~m}$. After following a trial and error approach, it was determined that a sampling rate of $0.005 \mathrm{~s}$ was necessary in order to achieve stable results. Therefore, a 40s simulation required 8000 time steps for a $780 \times 540 \times 220$ grid $\left(92.664 \times 10^{6}\right.$ nodes $)$.

The topography of the region is implemented on the computational grid on the basis of the methodology described by Ohminato and Chouet (1997). The initial 2D topographic grid is initially resampled with respect to the resolution of the computational grid $(100 \mathrm{~m})$, representing a staircase structure in the $3 \mathrm{D}$ space. Shear stresses are set to zero when they lie on vertical or horizontal surfaces or edges (depending on the specific stress component). Setting these values to zero is done by creating a series of grid "masks". These are 3D grids with each node having a value of zero or one and are used in order to multiply the separate stress 3D grids at each time step. In a same manner, normal stresses were set to zero on nodes that are over the topographic grid and at the same time the stress gradient at the free surface was multiplied by 2 (Ohminato and Chouet, 1997). The model 3D grid, including the 3D velocity structure and the topography is presented in Figure 3.

In order to eliminate artificial reflections in the side and bottom boundaries of the input computation grid, we implemented a combined absorbing and non- reflecting boundary condition, based on the methodology proposed by Liu and Sen (2009). More specifically, the absorbing boundary condition that we used is based on the $1^{\text {st }}$ Higdon one way wave equation (Higdon, 1991). The numerical formulas of this equation are applied on a strip of velocity nodes in the grid edges. The calculated velocity values in this region of the grid result from a weighted summation of the actual numerical formula provided by Graves (1996) and the one-way equation of Higdon (1991). In our case, a strip of 10 nodes on each boundary was sufficient in order to eliminate artificial reflections almost perfectly.

In our simulations, the source is represented by a finite surface, representing a fault. This surface has the geometrical characteristics of the fault (length, width, strike, dip). All grid points within this surface were treated as point sources, scaled with respect to their total number and are activated with a time delay, relative to the rupture speed. In our case we used a rupture velocity of $0.8 \mathrm{~V}_{\mathrm{S}}$ (e.g. Boatwright, 1980; Atkinson and Silva, 1997; Beresnev and Atkinson, 1998) and as an initial source we used the location of the hypocenter, which was the center of the fault plane for each tested fault. We also tested other possible hypocentral locations within the fault, but the resulting synthetics were highly similar. Each point source represents a double couple focal mechanism which is modeled on the velocity nodes, according to the 


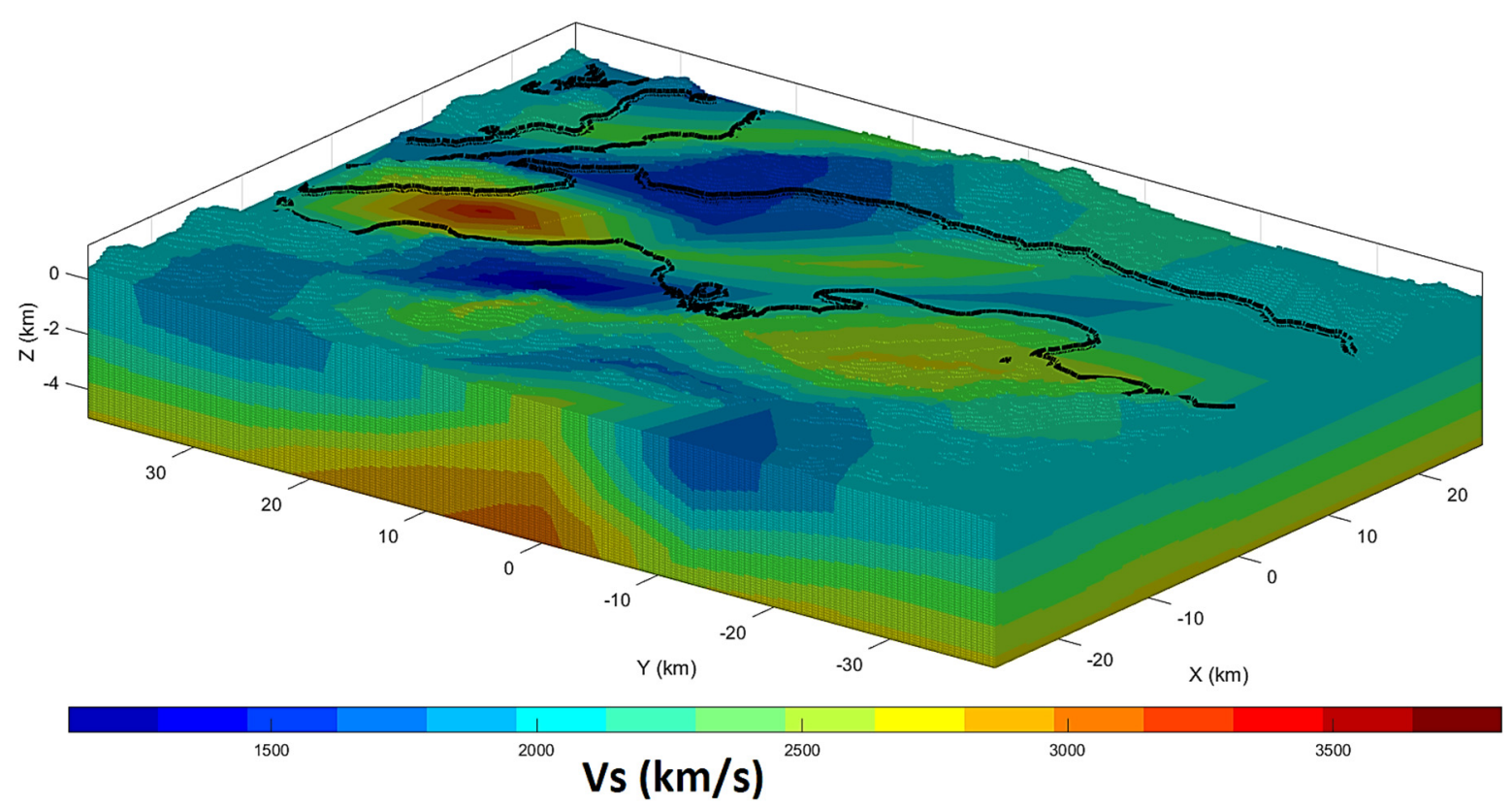

Fig. 3 The 3D simulation domain shown as a set of cubic cells with $\mathrm{dl}=100 \mathrm{~m}$ up to the depth of $5 \mathrm{~km}$ for the Northern Euboean Gulf. The vertical axis is exaggerated by a factor of 2.

technique proposed by Graves (1996). A Ricker wavelet with a frequency of $2 \mathrm{~Hz}$ was used as an initial pulse. To increase the computational efficiency for our simulations, we employed GPU processing (using a single $8 \mathrm{~Gb}$ GPU unit), instead of parallel processing (on our 16 cores CPU), which in our workstation resulted in a reduction of the simulation time by a factor of 30 .

\section{RESULTS}

The resulting normalized peak ground acceleration after the simulation for the three fault scenarios simulations can be seen in Figure 4a. It can be easily noticed that in the case of the Atalanti fault segment simulations, the highest modeled acceleration values were limited within the borders of the Atalanti basin, over the central part of the fault trace. As expected, the PGA distribution follows the strike of the fault trace; however at the northern and southern parts of the fault, these PGA values appear to be significantly lower. This can be justified by the fact that the topographic relief is characterized by abrupt rises, forming a small basin which acts as a trap for the seismic energy. Another contributing factor is the fact that the $V_{P}$ and $V_{S}$ velocities in that region are lower, compared to the southeastern part of the fault region, corresponding to the basin formations. A similar picture can be observed by examining the distribution of the spectral amplitudes, as seen in Figures 5a-6a. Also in this case, the maximum amplitudes for all simulated frequencies are contained within the Atalanti basin. The above observations are in contrast to the fact that the highest macroseismic intensities
(X on the EMS98 scale, according to the intensity estimations of Albini and Pantosti (2004), which were in turn based on several contemporary and later sources) for the main event were observed towards the southeast, in the area of the Malessina peninsula near the southeastern edge of the tested fault (Fig. 4a). The PGA distribution appears to be better correlated with the reported damages of the second event of 27/4/1984 (Fig. 7a), however it should be noted that the extensive damage after the first event caused bias in the reports on the damages of the second event, due to the accumulation of damage and thus macroseismic data for the southern region is less accurate in this case (Albini and Pantosti, 2004).

Carrying out the simulation using the fault proposed by Albini and Pantosti (2004), resulted in the highest acceleration amplitudes being observed closer to the northern part of the Malessina peninsula and the region of Tragana. Once again the PGA distribution is directly related to the location and orientation of the tested fault and thus, the shift of the maximum PGA values towards the southeast can be explained. In this case also however, there appears to be a significant reduction of the PGA values (Fig. 4b), as well as the spectral amplitudes (Figs. 5b-6b) towards the southeast, indicating the strong contribution of the $3 \mathrm{D}$ velocity model and the morphology to the simulated results. The largest acceleration values that were modelled for this fault case are now closer to the sites with the largest reported macroseismic intensities of the main event, compared to the previously tested fault. 

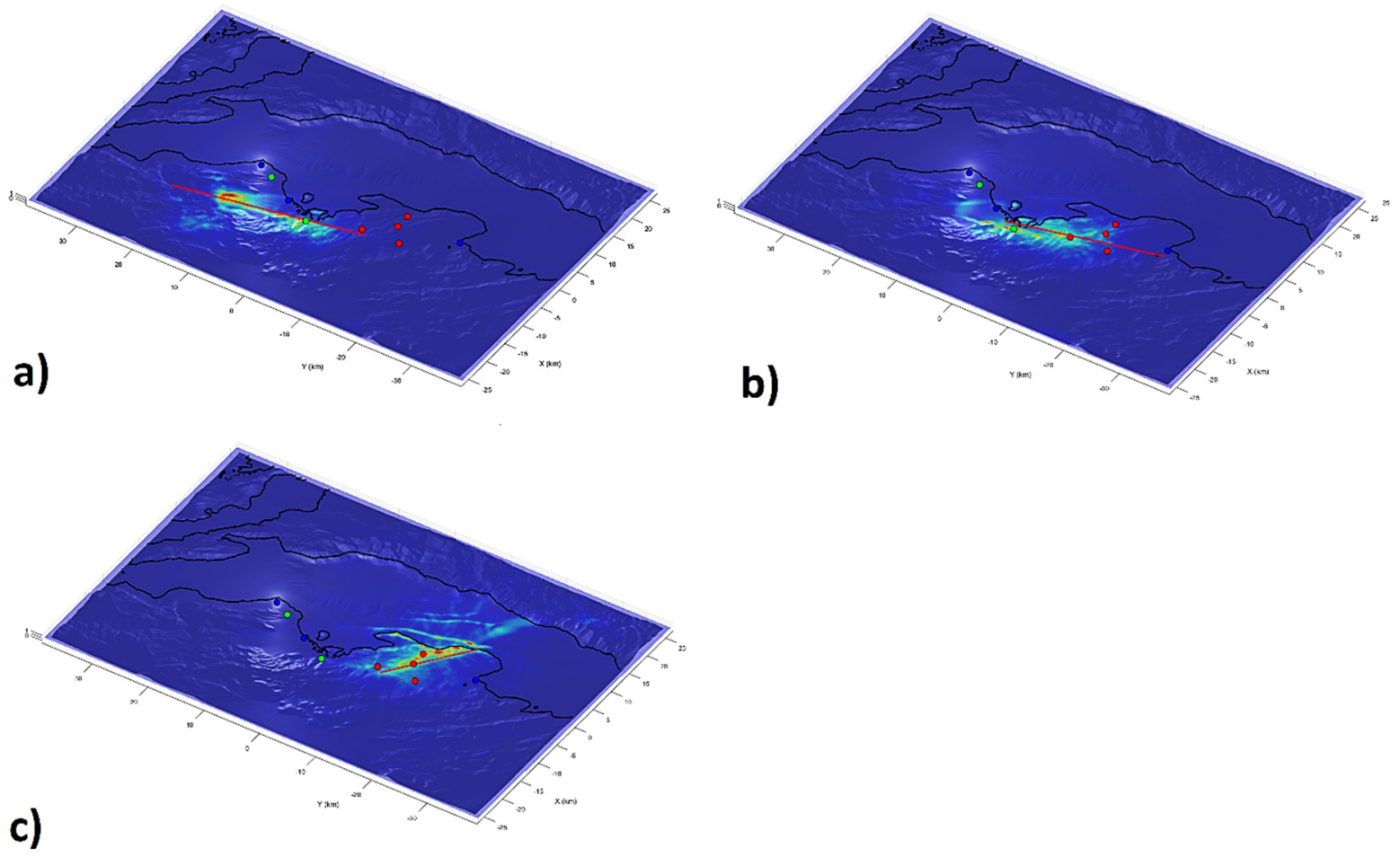

Fig. 4 The normalized simulated peak ground acceleration for the simulation cases of: a) the Atalanti fault segment, b) the fault proposed by Albini and Pantosti (2004) and c) the Malessina fault. The sites with reported macroseismic intensities for the event of 20/4/1894 of X are market with red symbols, the ones with intensity IX with green and the ones with intensity VIII-IX with blue (by Albini and Pantosti, 2004). The surface trace of the fault that was used as a source for each case is also marked with red line.
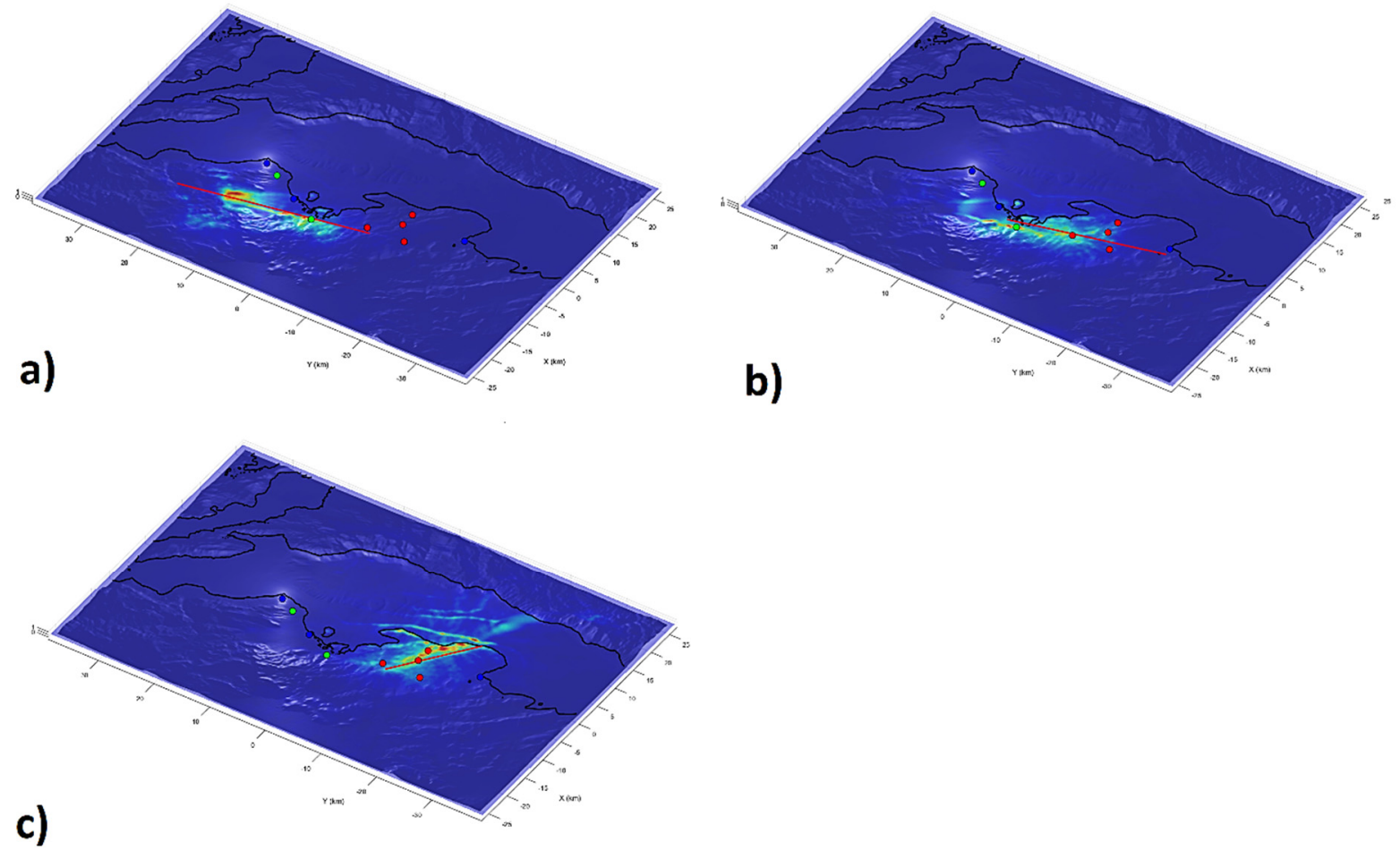

Fig. 5 a) The simulated spectral amplitudes for a frequency of $3 \mathrm{~Hz}$ for the three fault cases. Macroseismic intensities and the fault traces for each simulation case are shown as in Figure 4. 

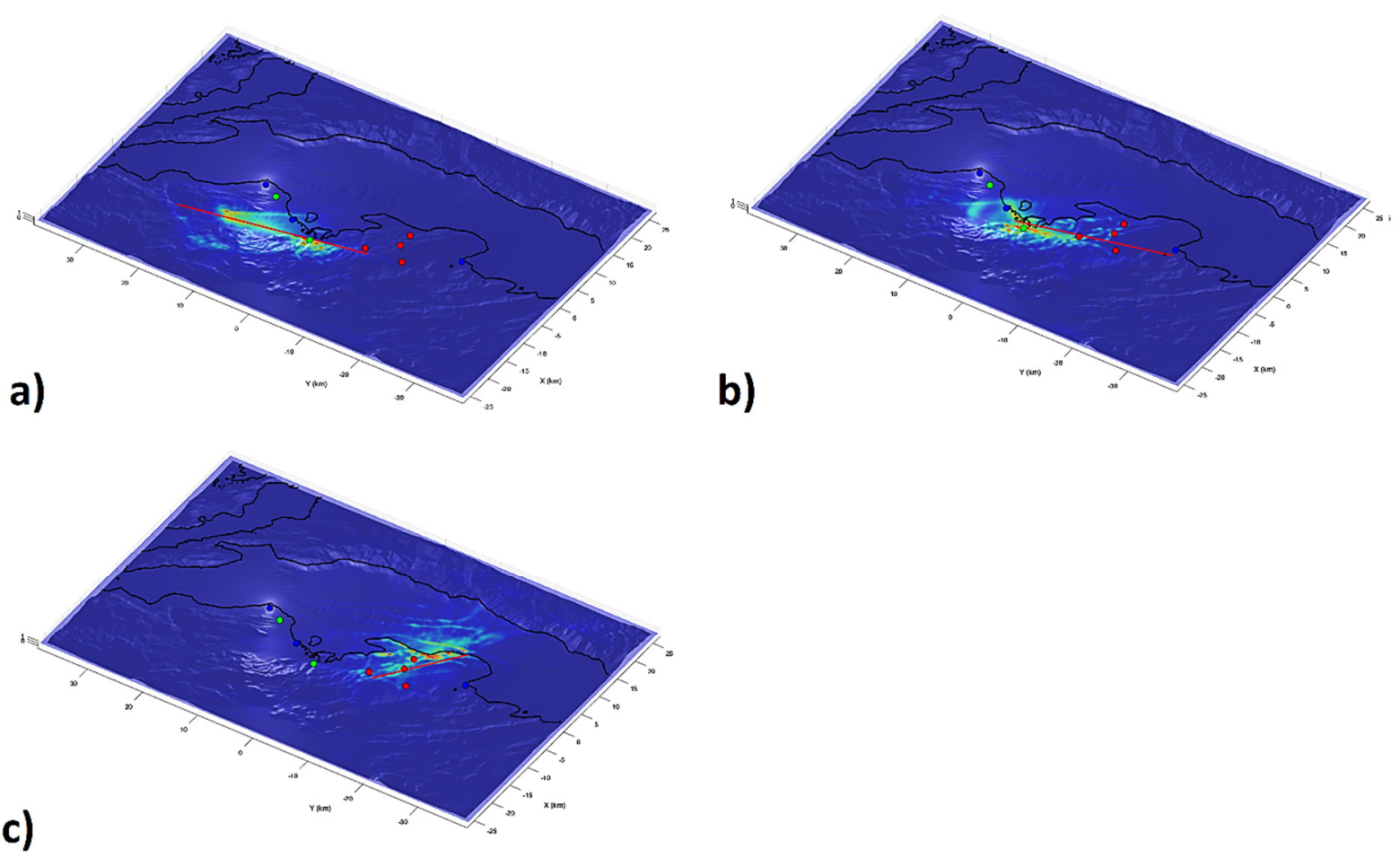

Fig. 6 a) The simulated spectral amplitudes for a frequency of $4 \mathrm{~Hz}$ for the three fault cases. Macroseismic intensities and the fault traces for each simulation case are shown as in Figure 4.

Figure $4 \mathrm{c}$ shows the results from carrying out the simulation for the Malessina fault. As seen in this case the PGA distribution follows an E-W trend, similar to the fault trace. Since the fault is further to the south of the Atalanti basin, the resulting PGA does not appear to be highly affected by this structure, and therefore the largest PGA values are now found over the central part of the Malessina peninsula, in total agreement with the largest reported macroseismic intensities of the main event. Concerning the spectral amplitudes, it can be seen that the largest values at frequencies $>2 \mathrm{~Hz}$ appear to be concentrated slightly to the eastern part of the fault area (Figs. 5c-6c). indicating the pronounced effect of the 3D structure on the simulated results. Furthermore, compared to the other two fault cases, some relatively larger PGA values, as well as spectral amplitudes at lower frequencies can be observed on the western coast of Euboea. It should be noted that the achieved bandwidth of the simulated results was between 0.2 and $4 \mathrm{~Hz}$.

Of the previously mentioned simulations, the one with the fault proposed by Albini and Pantosti (2004) (source 2) and the one with the Malessina fault (source 3) seem to produce PGA distributions that are better aligned with the largest macroseismic intensities that were recorded for the main event of 20/4/1987. For these two cases, we present in Figures 7-8 several snapshots of the simulated wavefields. It can be seen in Figure 7 that for the proposed fault used in the second simulation, a larger portion of the seismic energy appears to have travelled towards the southeast, crossing the Malessina peninsula. In contrast, the seismic energy diminishes much more rapidly as it travels northwards. This observation seems to indicate this fault as a possible source for this event. In Figure 8 snapshots of the simulated wavefield using the Malessina fault as a source are presented. As, expected, since the fault directly intersects the Malessina peninsula, a large portion of the seismic energy has crossed that region. At the same time, a significant portion of the seismic energy appears to have struck the northwestern region of Euboea, and in particular the region around the village of Limni (shown in Fig. 1). This observation is in line with the large reported macroseismic intensity value of VIII for the village of Limni; therefore, using this fault as a source for the main event appears to better explain the macroseismic observations compared to the previous test cases.

\section{CONCLUSIONS AND DISCUSSION}

In the present study we demonstrated a novel application of 3D numerical modeling for identifying the possible source of a historical event and attributing reported damages to the distribution of strong ground motion. By carrying out simulations for the two large historical earthquakes of 1894 in the region of Atalanti, using this 3D methodology in conjunction with a detailed 3D tomographic model, as well as the surface relief of the region, it was possible to 

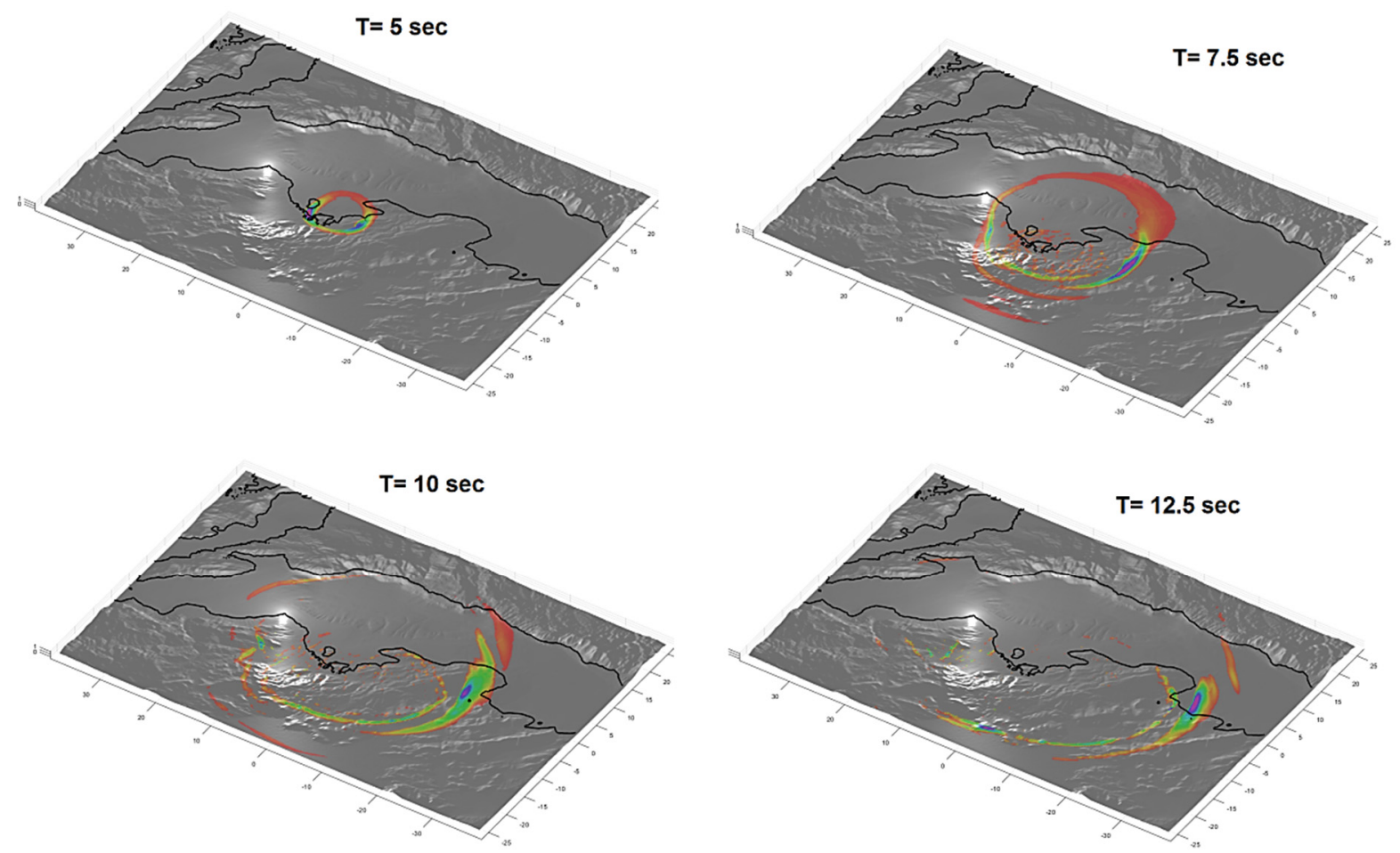

Fig. 7 Snapshots of the simulated velocity for a simulation with the fault proposed by Albini and Pantosti (2004) as a source.
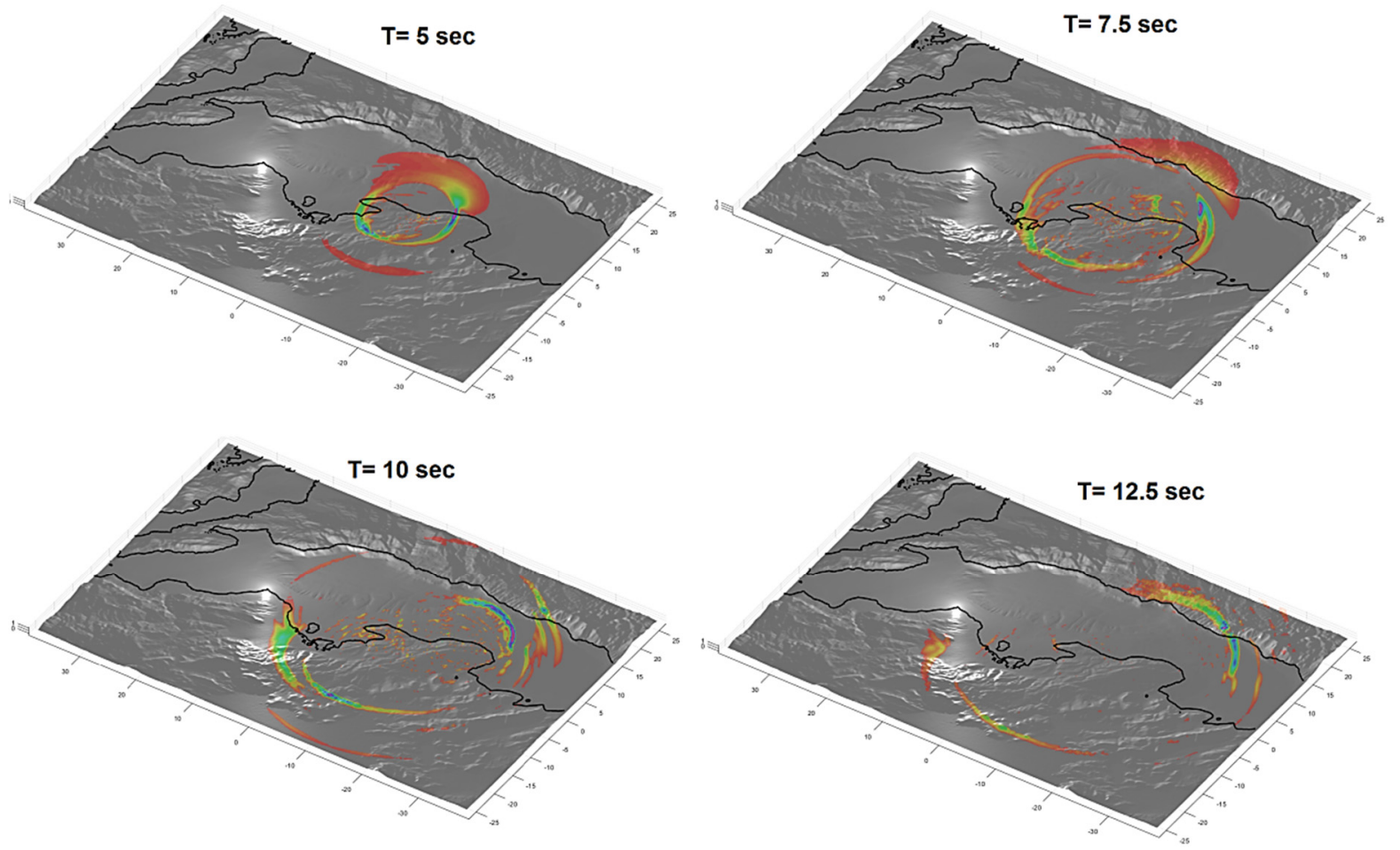

Fig. 8 Snapshots of the simulated velocity for a simulation with the Malessina fault as a source.

investigate the possible relation of the $3 \mathrm{D}$ structure with the reported damages for this event. Furthermore, using several proposed faults as possible sources, we further investigated which fault is the most probable source for these events based again on the reported distribution of macroseismic intensities. We should point out, however, that one of the most important factors with regards to the damage that may be caused by a strong earthquake is the local soil conditions. A detailed distribution of the shallow soil profile for 
such a wide region was not available in our case and therefore, this information was not contained in our simulations. Furthermore, even if this information was available, the input grid would have to be discretized in a resolution of only a few meters, which would result in an excessively large grid for such a large area and therefore it would not be possible to carry out the aforementioned simulations using the previously described methodology. Even without the inclusion however, the resulting simulated ground motion appears to be heavily influenced by the input 3D structure; therefore, a partial link between the localization of the damages and the resulting PGA distribution can be given.

It should also be pointed out that the present study was based on an old historical event, and therefore the information regarding the macroseismic intensities cannot be considered as perfectly accurate. Still, however, since the regional building environment could be considered homogeneous within this region, the reported distribution of the intensities cannot be far from the truth. In light of the above facts, the results of our simulations clearly point out towards the fault proposed by Albini and Pantosti (2004) and the Malessina fault as being the most probable sources for the 20/4/1894 event. Between the two cases the Malessina fault shows an even stronger correlation to the reported damages, based on the distribution of the PGA and therefore it should at least be considered as a possible candidate for this event. This particular fault has also been suggested by Gerolymatos and Stefouli (2020) as the source of this event. It should be further noted that for this fault case, the simulated spectral amplitudes at frequencies $>3 \mathrm{~Hz}$ show a very good correlation with the largest reported macroseismic intensities. Since the local building environment at that time included mostly small masonry buildings (Albini and Pantosti, 2004), which have resonant frequencies generally $>3 \mathrm{~Hz}$ (e.g. NTSC-2008, 2008; ASCE 07-16, 2017) it is expected that the ground motion at higher frequencies would be responsible for their total collapse. This further validates the Malessina fault as a probable source for this event.

\section{REFERENCES}

Albini, P. and Pantosti, D.: 2004, The 20 and 27 April 1894 (Locris, central Greece) earthquake sources through coeval records on macroseismic effects. Bull. Seismol. Soc. Am., 94, 4, 1305-1326.

Álvarez-Rubio, S., Sánchez-Sesma, F.J., Benito, J.J. and Alarcón, E.: 2004, The direct boundary element method: 2D site effects assessment on laterally varying layered media (methodology). Soil Dyn. Earthq. Eng., 24, 2, 167-180.

Ambraseys, N.: 2009, Earthquakes in the Mediterranean and Middle East: a multidisciplinary study of seismicity up to 1900 . Cambridge University Press, $947 \mathrm{pp}$.

Ambraseys, N. and Jackson, J.: 1990, Seismicity and associated strain of Central Greece between 1890 and 1988. Geophys. J. Int., 101, 663-708.
ASCE 07-16: 2017, Minimum Design Loads and Associated Criteria for Buildings and Other Structures. American Society of Civil Engineers, Virginia, NV, Reston.

Atkinson, G. M. and Silva, W.: 1997, An empirical study of earthquake source spectra for California earthquakes. Bull. Seismol. Soc. Am., 87, 1, 97-113.

Bard, P.Y. and Bouchon, M.: 1980, The seismic response of sediment-filled valleys. Part 1 . The case of incident $\mathrm{SH}$ waves. Bull. Seismol. Soc. Am., 70, 4, 1263-1286.

Bard, P.Y. and Gariel, J.C.: 1986, The seismic response of two-dimensional sedimentary deposits with large vertical velocity gradients. Bull. Seismol. Soc. Am., 76, 2, 343-366.

Benetatos, C., Kiratzi, A., Papazachos, C. and Karakaisis, G.: 2004, Focal mechanisms of shallow and intermediate depth earthquakes along the Hellenic Arc. J. Geodyn., 37, 2, 253-296. DOI: $10.1016 /$ j.jog.2004.02.002

Bonilla, L.F.: 2002, Computation of linear and nonlinear site response for near field ground motion. Ph.D. Dissertation, University of California, Santa Barbara.

Chavez-Garcia, F.J. and Bard, P.Y.: 1994, Site effects in Mexico City eight years after the September 1985 Michoacan earthquakes. Soil Dyn. Earthq. Eng., 13, 4, 229-247. DOI: 10.1016/0267-7261(94)90028-0

Chen, G. and Zhou, J.: 1992, Boundary element methods. London Academic Press.

de la Puente, J., Ampuero, J.P. and Käser, M. : 2009, Dynamic rupture modeling on unstructured meshes using a discontinuous Galerkin method. J. Geophys. Res., Solid Earth, 114, B10. DOI: $10.1029 / 2008 J B 00627$

Evelpidou, N., Pirazzoli, P.A., Saliège, J.F. and Vassilopoulos, A.: 2011, Submerged notches and doline sediments as evidence for Holocene subsidence. Cont. Shelf Res., 31, 12, 1273-1281. DOI: $10.1016 /$ j.csr.2011.05.002

Faccioli, E., Maggio, F., Quarteroni, A. and Tagliani, A.: 1996, Spectral domain decomposition methods for the solution of acoustic and elastic wave equations. Geophysics, 61, 4, 1160-1174. DOI: $10.1190 / 1.1444036$

Ferentinos, G., Brooks, M. and Doutsos, T.: 1985, Quaternary tectonics in the Gulf of Patras, western Greece. J. Struct. Geol. 7, 6, 713-717.

Frankel, A.: 1993, Three-dimensional simulations of ground motions in the San Bernardino Valley, California, for hypothetical earthquakes on the San Andreas fault. Bull. Seismol. Soc. Am., 83, 1020-1041.

Fu, H., He, C., Chen, B., Yin, Z., Zhang, Z., Zhang, W., ... and Chen, X.: 2017, 9-Pflops nonlinear earthquake simulation on Sunway TaihuLight: enabling depiction of $18-\mathrm{Hz}$ and 8 -meter scenarios. Proc. International Conference for High Performance Computing, Networking, Storage and Analysis. DOI: $10.1145 / 3126908.3126910$

Ganas, A.: 1997, Fault segmentation and seismic hazard assessment in the Gulf of Evia Rift, central Greece. Doctoral Dissertation, University of Reading.

Ganas, A., Roberts, G.P. and Memou, T.: 1998, Segment boundaries, the 1894 ruptures and strain patterns along the Atalanti fault, central Greece. J. Geodyn., 26, 2-4, 461-486. DOI: 10.1016/S0264-3707(97)00066-5 
Gerolymatos, I. and Stefouli, M.: 2020, Geomorphological/tectonic analysis of the Atalanti region: A new approach. 2nd workshop on Remote Sensing and Space Applications, Athens, (in Greek).

Goldsworthy, M. and Jackson, J.: 2001, Migration of activity within normal fault systems: examples from the Quaternary of mainland Greece. J. Struct. Geol., 23, 2, 489-506. DOI: 10.1016/S0191-8141(00)00121-8

Graves, R.W.: 1996, Simulating seismic wave propagation in 3D elastic media using staggered-grid finite differences. Bull. Seism. Soc. Am., 86, 4, 1091-1106.

Hatzfeld, D., Ziazia, M., Kementzetzidou, D., Hatzidimitriou, P., Panagiotopoulos, D., Makropoulos, K., ...and Deschamps, A.: 1999, Microseismicity and focal mechanisms at the western termination of the North Anatolian Fault and their implications for continental tectonics. Geophys. J. Int., $137,3,891-908$. DOI: 10.1046/j.1365-246x.1999.00851.x

Hestholm, S., Moran, M., Ketcham, S., Anderson, T., Dillen, M. and McMechan, G.: 2006, Effects of free-surface topography on moving-seismic-source modeling. Geophysics, 71, 6, T159-T166. DOI: $10.1190 / 1.2356258$

Higdon, R.L.: 1991, Absorbing boundary conditions for elastic waves. Geophysics, 56, 2, 231-241. DOI: $10.1190 / 1.1443035$

Hustedt, B., Operto, S. and Virieux, J.: 2004, Mixed-grid and staggered-grid finite-difference methods for frequency-domain acoustic wave modelling. Geophys. J. Int., 157, 3, 1269-1296.

DOI: $10.1111 /$ j.1365-246x.2004.02289.x

IGME - Institute of Geology and Mineral Exploration: 1983, Geological Map of Greece ( $\left.2^{\text {nd }} E d\right), 1: 500,000$ scale, Athens.

Jackson, J. and McKenzie, D.: 1999, A hectare of fresh striations on the Arkitsa fault, central Greece. J. Struct. Geol., 21, 1, 1-6.

DOI: $10.1016 / \mathrm{S} 0191-8141(98) 00091-1$

Joyner, W.B., Warrick, R.E. and Fumal, T.E.: 1981, The effect of Quaternary alluvium on strong ground motion in the Coyote Lake, California, earthquake of 1979. Bull. Seismol. Soc. Am., 71, 4, 1333-1349.

Kaneko, Y., Lapusta, N. and Ampuero, J.P.: 2008, Spectral element modeling of spontaneous earthquake rupture on rate and state faults: Effect of velocitystrengthening friction at shallow depths. J. Geophys. Res., Solid Earth, 113, B9. DOI: 10.1029/2007JB005553

Kanellopoulos, C., Argyraki, A. and Mitropoulos, P.: 2015, Geochemistry of serpentine agricultural soil and associated groundwater chemistry and vegetation in the area of Atalanti, Greece. J. Geochem. Explor., 158, 22-33. DOI: 10.1016/j.gexplo.2015.06.013

Kanellopoulos, C., Valsami-Jones, E., Voudouris, P., Stouraiti, C., Moritz, R., Mavrogonatos, C. and Mitropoulos, P.: 2018, A new occurrence of terrestrial native iron in the earth's surface: The Ilia thermogenic travertine case, northwestern Euboea, Greece. Geosci. J., 8, 287. DOI: $10.3390 /$ geosciences 8080287

Kanellopoulos, C., Vougioukalakis, G., Mavrogonatos, C., Megremi, I. and Iliopoulos, I.: 2019, Mineralogical, petrological and geochemical study of the Agios Ioannis Volcanic Rocks, Kamena Vourla Area, Greece. Bull. Geol. Soc. Greece, 55, 274-289. DOI: $10.12681 /$ bgsg. 21128
Kanellopoulos, C., Xenakis, M., Vakalopoulos, P., Kranis, H., Christopoulou, M. and Vougioukalakis, G.: 2020, Seawater-dominated, tectonically controlled and volcanic related geothermal systems: the case of the geothermal area in the northwest of the island of Euboea (Evia), Greece. Int. J. Earth Sci., 109, 6, 20812112. DOI: $10.1007 / \mathrm{s} 00531-020-01889-7$

Karastathis, V.K., Ganas, A., Makris, J., Papoulia, J., Dafnis, P., Gerolymatou, E. and Drakatos, G.: 2007, The application of shallow seismic techniques in the study of active faults: The Atalanti normal fault, central Greece. J. Appl. Geophys., 62, 3, 215-233.

DOI: $10.1016 /$ j.jappgeo.2006.11.004

Karastathis, V.K., Papadopoulos, G.A., Novikova, T., Roumelioti, Z., Karmis, P. and Tsombos, P.: 2010, Prediction and evaluation of nonlinear site response with potentially liquefiable layers in the area of Nafplion (Peloponnesus, Greece) for a repeat of historical earthquakes. Nat. Hazards Earth Syst. Sci., $10,11,2281-2304$. DOI: $10.5194 /$ nhess-10-2281-2010

Karastathis, V.K., Papoulia, J., Di Fiore, B., Makris, J., Tsambas, A., Stampolidis, A. and Papadopoulos, G.A.: 2011, Deep structure investigations of the geothermal field of the North Euboean Gulf, Greece, using 3-D local earthquake tomography and Curie Point Depth analysis. J. Volcanol. Geotherm. Res., 206, 3-4, 106-120.

DOI: $10.1016 /$ j.jvolgeores.2011.06.008

Karnik, V.: 1971, The Seismicity of the European Area, Vol. 2. Reidel Publishing Co., Dordrecht, the Netherlands.

Komatitsch, D. and Vilotte, J.P.: 1998, The Spectral Element Method: An efficient tool to simulate the seismic response of 2D and 3D geological structures. Bull. Seismol. Soc. Am., 88, 368-392.

Kranis, H.D., Palyvos, N., Livaditis, G. and Maroukian, H.: 2001, The Hyambolis zone: Geomorphological and tectonic evidence of a transverse structure in Lokris (Central Greece). Bull. Geol. Soc. Greece, 34, 1, 251257.

Leeder, M.R. and Jackson, J.A.: 1993, The interaction between normal faulting and drainage in active extensional basins, with examples from the western United States and central Greece. Basin Res., 5, 2, 79 102. DOI: 10.1111/j.1365-2117.1993.tb00059.x

Levander, A.R.: 1988, Fourth-order finite-difference P-S. Geophysics, 53, 11, 1425-1436. DOI: $10.1190 / 1.1442422$

Liu, Y. and Sen, M.K.: 2009, An implicit staggered-grid finite-difference method for seismic modelling. Geophys. J. Int., 179, 1, 459-474. DOI: $10.1111 / \mathrm{j} .1365-246 X .2009 .04305 . x$

Liu, S., Li, X., Wang, W. and Liu, Y.: 2014. A mixed-grid finite element method with PML absorbing boundary conditions for seismic wave modelling. J. Geophys. Eng., 11, 5, 055009.

DOI: $10.1088 / 1742-2132 / 11 / 5 / 055009$

Lybéris, N.: 1984, Tectonic evolution of the North Aegean trough. Geological Society, London, Special Publications, 17, 709-725. DOI: 10.1144/GSL.SP.1984.017.01.57

Makris, J., Papoulia, J., Papanikolaou, D. and Stavrakakis, G.: 2001, Thinned continental crust below northern Evoikos Gulf, central Greece, detected from deep seismic soundings. Tectonophysics, 341, 1-4, 225236. DOI: 10.1016/S0040-1951(01)00186-X 
Makropoulos, K.C. and V. Kouskouna: 1994, The 1894 April 20 and 27 Atalanti earthquakes: 100 years afterLessons learnt. Proc. ESC XXIV Gen. Ass., Athens, Vol. 1, 61-71.

Mettos, A., Rondogianni, T., Papadakis, I., Paschos, P. and Georgiou, C.: 1991, New data on the geology of the Neogene deposits of N. Evia. Bull. Geol. Soc. Greece, $25,3,71-83$.

Minster, J., Olsen, K.B., Moore, R., Day, S., Maechling, P., Jordan, T., ... and Lopez, J.: 2004, The SCEC TeraShake earthquake simulation. AGU Fall Meeting Abstracts, vol. 2004, SF31B-05.

Nixon, C.W., McNeill, L.C., Bull, J.M., Bell, R.E., Gawthorpe, R.L., Henstock, T.J., ... and Ferentinos, G.: 2016, Rapid spatiotemporal variations in rift structure during development of the Corinth Rift, central Greece. Tectonics, 35, 5, 1225-1248. DOI: 10.1002/2015TC004026

Novikova, T., Mouzakiotis, E. and Karastathis, V.K.: 2017, Magnitude assessment for the historical earthquake based on strong-motion simulation and liquefaction analysis: Case of the 1894 Atalanti earthquake, Greece. Bull. Seismol. Soc. Am., 107, 1, 418-432. DOI: $10.1785 / 0120150267$

NTC-2008: 2008, Norme Tecniche per le Costruzioni. D.M. $14 / 01 / 2008$, S.O. n. 30 of the Official Gazette of the Italian Republic 2008, (in Italian).

Ohminato, K. and Chouet, B.: 1997, A free-surface boundary condition for including $3 \mathrm{D}$ topography in the Finite-Difference Method. Bull. Seismol. Soc. Am., 87, 2, 494-515. 10.1785/BSSA0870020494

Ori, G.G.: 1989, Geologic history of the extensional basin of the Gulf of Corinth (?Miocene-Pleistocene), Greece. Geology, 17, 10, 918-921. DOI: $10.1130 / 0091-7613(1989) 017$

Padovani, E., Priolo, E. and Seriani, G.: 1994, Low and high order finite element method: experience in seismic modeling. J. Comput. Acoust., 2, 4, 371-422. DOI: $10.1142 / \mathrm{s} 0218396 \times 94000233$

Palyvos, N., Bantekas, I. and Kranis, H.: 2006, Transverse fault zones of subtle geomorphic signature in northern Evia island (central Greece extensional province): An introduction to the Quaternary Nileas graben. Geomorphology, 76, 3-4, 363-374. DOI: 10.1016/J.GEOMORPH.2005.12.002

Pantosti, D., De Martini, P.M., Papanastassiou, D., Palyvos, N., Lemeille, F. and Stavrakakis, G.: 2001, A reappraisal of the 1894 Atalanti earthquake surface ruptures, central Greece. Bull. Seismol. Soc. Am., 91, 4, 760-780. DOI: 10.1785/0120000051

Papanastassiou, D., Cundy, A.B., Gaki-Papanastassiou, K., Frogley, M.R., Tsanakas, K. and Maroukian, H.: 2014, The uplifted terraces of the Arkitsa region, NW Evoikos Gulf, Greece: a result of combined tectonic and volcanic processes? J. Geol., 122, 4, 397-410. DOI: $10.1086 / 676595$

Papazachos, B.C. and Papazachou, K.: 2003, The earthquakes of Greece. Ziti Editions, Thessaloniki, Greece, 286 pp. (in Greek).

Pavlides, S.B., Valkaniotis, S., Ganas, A., Keramydas, D. and Sboras, S.: 2004, The Atalanti active fault: Reevaluation using new geological data. Bull. Geol. Soc. Greece, 36, 4, 1560-1567. DOI: 10.12681/bgsg.16545

Pelties, C., De la Puente, J., Ampuero, J.P., Brietzke, G.B. and Käser, M.: 2012, Three-dimensional dynamic rupture simulation with a high-order discontinuous
Galerkin method on unstructured tetrahedral meshes. J. Geophys. Res., Solid Earth, 117, B2. DOI: $10.1029 / 2011$ jb008857

Pitarka, A., Irikura, K., Iwata, T. and Sekiguchi, H.: 1998, Three-dimensional simulation of the near-fault ground motion for the 1995 Hyogo-ken Nanbu (Kobe), Japan, earthquake. Bull. Seismol. Soc. Am., 88, 2, 428-440. DOI: $10.1785 /$ BSSA0880020428

Poulimenos, G. and Doutsos, T.: 1997, Flexural uplift of rift flanks in central Greece. Tectonics, 16, 6, 912-923. DOI: $10.1029 / 97 \mathrm{TC} 01658$

Resor, P.G. and Meer, V.E.: 2009, Slip heterogeneity on a corrugated fault. Earth Planet. Sci. Lett., 288, 3-4, 483-491. DOI: 10.1016/j.eps1.2009.10.010.

Roberts, S. and Jackson, J.: 1991, Active normal faulting in central Greece: an overview. Geol. Soc. London, Spec. Publ., 56, 125-142. DOI: 10.1144/GSL.SP.1991.056.01.09

Rubio, F., Hanzich, M., Farrés, A., De La Puente, J. and Cela, J.M.: 2014, Finite-difference staggered grids in GPUs for anisotropic elastic wave propagation simulation. Comput. Geosci., 70, C, 181-189. DOI: 10.1016/j.cageo.2014.06.003

Sboras, S., Chatzipetros, A. and Pavlides, S.: 2017, North Aegean active fault pattern and the 24 May 2014, Mw 6.9 earthquake. In: Active global seismology: neotectonics and earthquake potential of the Eastern Mediterranean Region. John Wiley and Sons Inc., 239-272.

Semblat, J.F.: 2011, Modeling seismic wave propagation and amplification in $1 \mathrm{D} / 2 \mathrm{D} / 3 \mathrm{D}$ linear and nonlinear unbounded media. Int. J. Geomech., 11, 6, 440-448. DOI: $10.1061 /($ ASCE)GM.1943-5622.0000023

Shebalin, N.V., Karnik, V. and Hadzievski, D.: 1974, Catalogue of earthquakes of the Balkan region, I. UNDP-UNESCO Survey of the seismicity of the Balkan region. Skopje, 600 pp.

Stiros, S.C. and Rondogianni, T.: 1985, Recent vertical movements across the Atalandi fault-zone (central Greece). Pure Appl. Geophys., 123, 6, 837-848.

Stiros, S.C., Arnold, M., Pirazzoli, P.A., Laborel, J., Laborel, F. and Papageorgiou, S.: 1992, Historical coseismic uplift on Euboea island, Greece. Earth Planet. Sci. Lett., 108, 1-3, 109-117. DOI: $10.1016 / 0012-821 X(92) 90063-2$

Tago, J., Cruz-Atienza, V.M., Virieux, J., Etienne, V. and Sánchez-Sesma, F.J.: 2012, A 3D hp-adaptive discontinuous Galerkin method for modeling earthquake dynamics. J. Geophys. Res., Solid Earth, 117, B9, 9312. DOI: 10.1029/2012JB009313

Virieux, J.: 1984, SH-wave propagation in heterogeneous media: velocity-stress finite-difference method. Explor. Geophys., 15, 4, 265. DOI: $10.1071 / \mathrm{EG} 984265 \mathrm{a}$

Yilmaz, O., Eser, M. and Berilgen, M.: 2006, A case study of seismic zonation in municipal areas. Lead. Edge, 25, 3, 319-330. DOI: 10.1190/1.2184100

Zhang, W., Shen, Y. and Zhao, L.: 2012, Three-dimensional anisotropic seismic wave modelling in spherical coordinates by a collocated-grid finite-difference method. Geophys. J. Int., 188, 3, 1359-1381. DOI: 10.1111/j.1365-246X.2011.05331.x

Zienkiewicz, O.C., Taylor, R.L., Nithiarasu, P. and Zhu, J.Z.: 1977, The finite element method, Vol. 3. London, McGraw-Hill. 